\title{
Resilient or reckless? Robust debate on risk and reward in sport
}

\author{
Jon Patricios ${ }^{1,2}$
}

Strong, vigorous, sturdy and rugged are all synonyms applicable to the word 'robust'. A glass of full-bodied South African cabernet sauvignon may also be described by the sommelier as 'robust' and I hope that this South African Sports Medicine Association (SASMA) edition of BJSM will linger on your intellectual palate as it highlights key issues around the debate on contact and collision sport.

\section{HIGHLIGHTING POTENTIAL RISKS}

The infographic (see page 1165) highlights the many benefits of exercise for children. Do these benefits extend to contact and collision sports or are the risks indefensible? The 'risk-and-reward' discussion is fascinating as it spans the realms of both scientific and public debate. This can be treacherous territory.

Implementing robust scientific findings into practice is what we strive for, but when does private and public opinion begin to inform 'scientific' work? Professor Allyson Pollock and a group of '70 academics, doctors and public health professionals' sent an open letter to the British government in 2016 calling for a ban on tackling in school rugby. ${ }^{2}$ Pollock's review 'Evidence in support of the call to ban the tackle and harmful contact in school rugby. A response to World Rugby' (see page 1113) brings this issue into our scientific and clinical domain. Publishing what many may regard as an opinion piece in BJSM is contentious but can be defended in the interest of subjecting the issues raised to more systematic scrutiny.

Critics (and indeed the reviewers) of the Pollock group's work may take issue with an apparent inconsistent application of rules, cherry picking of facts, self-contradictory statements, selective use of data subsets and straw man fallacy. Is this a methodical and valid review or political

\footnotetext{
${ }^{1}$ University of Pretoria, Section of Sports Medicine, Faculty of Health Sciences, Johannesburg, South Africa ${ }^{2}$ Department of Emergency Medicine, Faculty of Health Sciences, University of the Witwatersrand, Johannesburg, South Africa
}

Correspondence to Dr Jon Patricios, Section of Sports Medicine, Faculty of Health Sciences, University of Pretoria, Pretoria, Johannesburg 2121, South Africa; jpat@mweb.co.za advocacy masquerading as scientific work? Hence, the Kirkwood paper should, indeed must, be read in the context of the Ken Quarrie-led review (see page 1134), using the example of rugby.

\section{TACKLING THE ISSUE...}

Several papers highlight research into risk reduction in contact sport that provide a constructive alternative to the 'ban tackling' approach. Michael Hislop and Keith Stokes' group (see page 1140) publish a large cluster-randomised controlled trial demonstrating that a preventative movement control exercise programme can reduce injuries, including concussion, in schoolboy rugby players.

The Berlin Concussion Consensus meeting highlighted the potential for sideline video analysis to help identify concussions. ${ }^{3}$ Ross Tucker (www. sportsscience.com and @ScienceofSport) takes this further, using video analysis to analyse head injury events in Rugby Union in two linked pieces (see page 1147, see page 1152) of original research. (Tip: look out for more Rugby video injury analysis work from the RFU in the pages of BJSM soon...)

\section{SOUTH AFRICA'S @BOKSMART}

What would a SASMA-edition be without a contribution from BokSmart, South African Rugby's world-renowned injury intervention programme? James Brown and Wayne Viljoen outline BokSmart's ambition of VisionZero catastrophic injuries (see page 1106) while co-author Australian epidemiologist Caroline Finch leads another editorial highlighting the work of BokSmart, The $11+$, FootyFirst and other injury sports injury prevention programmes (see page 1109).

The heading in football discussion is another that has easily found its way into the lay press. ${ }^{4}$ In the most thorough systematic review yet undertaken, Anthony Kontos' meta-analysis finds no conclusive evidence for adverse outcomes from heading the football (see page 1118). This is likely to be highly cited work.

Hot off the press is the World Rugby-led Concussion Implementation Meeting Dublin, July 2017. A collaboration of eight core sports (Australian Football, International Equestrian,
FIFA, International Ice Hockey, IOC, NFL, Rugby League and World Rugby) designed to get the Best out of Berlin.

\section{ON THE SIDELINE....}

For those who are not into tackling as a pastime, there are still some enthralling clinically-relevant titbits in this edition: the PEDro synthesis on ACL injury prevention exercises (see page 1161), a $B M J$ synopsis on acute achilles ruptures (see page 1158) and Johann Windt's latest personality profile, this time with the \#AnnoyinglyPersistentButReliable Brit in Oz, Liam West.

THE REWARD: SASMA CONGRESS 2017 The biennial SASMA Congress takes place in the shadow of Table Mountain, Cape Town from 24-27 October. Inspired by the Cape's fine wines, there will be a blend of fruity topics, raw science and delectable discussions (programme available at http:/www.sasma2017.co. za/index.php/programme). Meet South African sports medicine stalwarts and the BokSmart team, raise a rugby debate with Ross Tucker, and a glass of Rose' with legendary Willem van Mechelen. A paediatric sports medicine course is on offer. Prof Aurelia Nattiv, an expert in women's health medicine, will present the opening Noble Lecture. Kudos to convenor and SASMA President, Dr Phatho Zondi-terrific sports medicine leadership. Like the wine, this Congress keeps improving each passing year.

\section{Competing interests None declared.}

Provenance and peer review Commissioned; internally peer reviewed.

(C) Article author(s) (or their employer(s) unless otherwise stated in the text of the article) 2017. All rights reserved. No commercial use is permitted unless otherwise expressly granted.

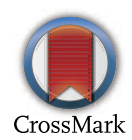

To cite Patricios J. Br J Sports Med 2017;51:1105.

Br J Sports Med 2017;51:1105

doi:10.1136/bjsports-2017-098142

\section{REFERENCES}

1 https://en.oxforddictionaries.com/definition/robust (accessed 6 Jun 2017)

2 http://www.qmul.ac.uk/media/news/items/smd/171584. html (accessed 6 Jun 2017)

3 Patricios J, Fuller GW, Ellenbogen $\mathrm{R}$, et al. What are the critical elements of sideline screening that can be used to establish the diagnosis of concussion? A systematic review. Br J Sports Med 2017;51:888-94.

4 http://www.foxnews.com/health/2017/02/03/ heading-in-soccer-may-lead-to-concussion-symptoms. htmlAcceesed (accessed 6 Jun 2016) 


\section{Correction: Resilient or reckless? Robust debate on risk and reward in sport}

Patricios J. Resilient or reckless? Robust debate on risk and reward in sport. Br J Sports Med 2017;51:1105. doi:10.1136/bjsports-2017-098142.

The correct competing interests statement should be:

Dr Jon Patricios was an unpaid advisor to South African Rugby's BokSmart programme and a voluntary member of World Rugby's Concussion Advisory Group.

(C) Author(s) (or their employer(s)) 2020. No commercial re-use. See rights and permissions. Published by BMJ. Br J Sports Med 2020;54:e1. doi:10.1136/bjsports-2017-098142corr1

(D) Check for updates 